\title{
Correction to: The Effects of Parental Labor Migration on Children's Mental Health in Rural China
}

\author{
Hechao Jiang ${ }^{1}\left(\mathbb{D} \cdot\right.$ Taixiang Duan $^{2} \cdot$ Fang Wang $^{3}$
}

Published online: 23 October 2021

(c) The Author(s) 2021

\section{Correction to: Applied Research in Quality of Life https://doi.org/10.1007/s11482-021-09989-5}

The article "The Effects of Parental Labor Migration on Children's Mental Health in Rural China", written by Hechao Jiang, Taixiang Duan, and Fang Wang, was originally published electronically on the publisher's internet portal on 14 September 2021 without open access. With the author(s)' decision to opt for Open Choice the copyright of the article changed on 04 October 2021 to $\odot$ The Author(s) 2021 and the article is forthwith distributed under a Creative Commons Attribution 4.0 International License, which permits use, sharing, adaptation, distribution and reproduction in any medium or format, as long as you give appropriate credit to the original author(s) and the source, provide a link to the Creative Commons licence, and indicate if changes were made. The images or other third party material in this article are included in the article's Creative Commons licence, unless indicated otherwise in a credit line to the material. If material is not included in the article's Creative Commons licence and your intended use is not permitted by statutory regulation or exceeds the permitted use, you will need to obtain permission directly from the copyright holder. To view a copy of this licence, visit http://creativecommons.org/licenses/by/4.0.

The original article has been corrected.

Open Access This article is licensed under a Creative Commons Attribution 4.0 International License, which permits use, sharing, adaptation, distribution and reproduction in any medium or format, as long as you give appropriate credit to the original author(s) and the source, provide a link to the Creative

The original article can be found online at https://doi.org/10.1007/s11482-021-09989-5.

Hechao Jiang

jhchao@swufe.edu.cn

1 Research Institute of Social Development, Southwestern University of Finance and Economics, Chengdu, No. 555, Liutai Road, Wenjiang District, 611130 Chengdu, People's Republic of China

2 Department of Sociology, Hohai University, Nanjing, People's Republic of China

3 Department of Sociology, Xi' an Jiaotong University, Xi' an, People's Republic of China 
Commons licence, and indicate if changes were made. The images or other third party material in this article are included in the article's Creative Commons licence, unless indicated otherwise in a credit line to the material. If material is not included in the article's Creative Commons licence and your intended use is not permitted by statutory regulation or exceeds the permitted use, you will need to obtain permission directly from the copyright holder. To view a copy of this licence, visit http://creativecommons.org/ licenses/by/4.0/.

Publisher's Note Springer Nature remains neutral with regard to jurisdictional claims in published maps and institutional affiliations. 